\title{
Environmental sustainability in local governments: A case of Turkish municipalities
}

\author{
Seda Yıldırım1, Seda H. Bostanc ${ }^{2^{\star}}$ and Seyfettin Erdoğan ${ }^{3}$ \\ ${ }^{1}$ Department of Business Administration, Faculty of Economics and Administrative Sciences,Namık Kemal University, \\ Tekirdağ, Turkey. \\ ${ }^{2}$ Department of Political Science and Public Administration, Faculty of Economics and Administrative Sciences, \\ Namık Kemal University, Tekirdağ, Turkey. \\ ${ }^{3}$ Department of Economics, Faculty of Political Science, Medeniyet University, Istanbul, Turkey.
}

Received 20 September, 2017; Accepted 17 October, 2017

\begin{abstract}
This study investigated the level of perception and understanding of local government staff about environmental sustainability tools and implementations in the city of Istanbul in Turkey. It employed qualitative methods and the data was collected via interview method. The study adapted Bostancı's eco-municipality researches to investigate sustainability tools of municipalities in Turkey. According to this research, issues such as LA 21's appendage as city councils, strategies of directory of environment, sustainable urban planning, green transportation, waste management, urban transformation, renewable energy projects, social activities, green certified public buildings and energy productivity projects were evaluated by the municipal staff whether the issues were sufficient or insufficient. The qualitative findings indicated that strategy-based implementations such as sustainable planning, participator policies, and laws were more successful than project-based implementations such as renewable energy projects, green transportations etc. In addition, some evidences show that staff of local governments knew the importance of sustainability but there is some lack of practices. From the findings, this approach supports the argument that each local government should have their own Local Agenda 21 program. Also, the study offers local governments to keep guidance of International Conference on Language, Education and Innovation (ICLEI) and LA 21 program for sustainable development in the long-term. With the findings, the study can be a good sample for the municipality which has been following LA 21 program for a long time.
\end{abstract}

Key words: Local governments, municipality, environmental sustainability, sustainable development, Local Agenda 21, Istanbul-Turkey.

\section{INTRODUCTION}

Air or water which are basic elements of natural environment are not economic goods for humanity, and are thought as public goods generally. Accordingly, it can be said that public sector is responsible for sustainability

*Corresponding author. E-mail: shbostanci@nku.edu.tr.

Author agree that this article remain permanently open access under the terms of the Creative Commons Attribution License 4.0 International License 
of clean air, water, environment etc (Emas, 2015). The last decades has warned against climate changes and decreasing natural resources and as such, sustainability of generation has become the basic aim in every area such as the economy, engineering, business etc. On this note, governments took the first responsibility for sustainable development and revised every public implementation to be more sustainable. United Cities and Local Governments (UCLG) (2015) determined new future goals for local governments to reach sustainable development, and many local governments which are members of UCLG came together to discuss what kinds of aims should be adopted for future years (UCLG, 2015). These future goals are called "The 2030 Agenda for Sustainable Development" and bring so many responsibilities to local and regional governments (KOMMUNESPEILET, 2016). In addition, there are formal organizations that guide local and regional governments for sustainability. On this note, it can be said that one of the most effective organization is ICLEI (Local Governments for Sustainability). ICLEI leads local and regional governments for sustainable development by working sustainability and carrying out conferences and reports in this area (ICLEI, 2017). With the help of ICLEI, local governments can learn much more information and implementation about sustainability. Turkey which is one of the emerging economies in the world is also a member of ICLEl. The present study has shown that the world should recognize the growth of emerging economies and the need for sustainable development for the future. Accordingly, investigating emerging economies within a sustainable development will be valuable. This study investigates the perception of the staff of local governments with respect to environmental sustainability tools in Istanbul-Turkey as a sample of emerging economy.

\section{Local agenda 21 and municipalities}

United Nations Conference on the Human Environment (1972) introduced "sustainable development" formally to the world at first and the term sustainability has been linked to economic life ever since. "Our Common Future" report was discussed in 1987 by the Brundtland Commission (Upadhyay and Brinkmann, 2010) and then, the United Nations Conference on Environment and Development held in Rio de Janerio in 1992 and Agenda 21 was born. This conference presented the importance of sustainable development both globally and nationally in terms of countries, and emphasized the necessity of sustainability in countries' management strategies in terms of the green economy (Yıldırım et al., 2016). According to the Brundtland Commission's definition, sustainable development can be explained as "an ability to have development sustainability - meeting the present needs with protecting needs of the next generation" (Kates et al., 2016). For local governments, sustainable development is thought as local economic development such that by supporting environmental sustainability (Strong and Dowdeswell, 1996) it can be said that local governments should be interested in LA 21 much more than others. Practices of LA 21 have been carried out in the coordination of the $21^{\text {st }}$ century's sustainability targets among countries (Lafferty and Eckerberg, 2009). Each local government has had to adapt their own LA21 strategy to reach sustainable point in the long term (Sustainable Environment, 2017). There are four basic sections in the LA 21 such as "social and economic dimensions, conservation and management of resources for development, strengthening the role of major groups, and means of implementation" (UNCED, 1992). The third section of Agenda 21, titled 'Strengthening the Role of Major Groups', refers to the formation of local authorities to support the Agenda 21. What is listed in the chapter 28 , titled Local Authorities' Initiatives, formed the basis of the agreement of sustainability principles in urban managements and formation of the process known as the LA 21" (Atvur, 2009). If sustainable development provides the balance between economic, community (social) and ecological issues in the big picture, then the LA 21 provides the balance between economic, social and environmental issues of the related city, town or region (Strong and Dowdeswell, 1996), because local governments works for the city's need of products and services and meet citizens social needs at the same time. As determined in Chapter 28 of LA 21, local governments are more close to the people of the city and they can play a more effective role in sustainable development (Connelly, 2002). Considering the importance of sustainable development, there should also be a measure to determine the performance of local governments for sustainable implementations. At this point, some studies investigated alternative scales used to measure the degree of sustainability. Tanguay et al. (2010) investigated indicators of sustainable development for local governments and analyzed 17 studies that included sustainable development indicators (SDI) in developed western countries. Scipioni et al. (2009) investigated sustainability performance of Padua Municipality (in Italy) as a sample of local government through the dashboard of sustainability (DS). They found that the LA 21 program helped Padua's community to obtain sustainability and they also tested the tool of DS if it can be a useful measurement to determine sustainability performance of the local governments.

The LA 21 program can also be a useful indicator for local governments to determine the level for sustainable development. Most local governments have begun the LA21 program and adapted it for their country. Czech 
Republic began the LA 21 in the 1990s and its municipalities has engaged with LA21 (CENIA, 2008). CENIA (2008) reported the development of the LA21 program in Czech Republic and it was explained that municipalities were much more interested in LA 21. The Southern Australian Government and the Local Government Association (1995) set the Partnership for LA 21. The Partnership aims to achieve goals of LA 21 program in the Southern Australia. In the report of LA 21 for Southern Australia, it was examined that sustainability is so important for cities and the process of LA 21 program for Southern Australia (Partnership for LA 21, 1999). Roberts and Diederichs (2002) examined LA 21 for Southern Africa. They investigated Durban's LA 21 program and presented the development degree of Durban's LA 21 program. Eckerberg and Forsberg (1998) investigated Agenda 21 for Swedish local government. They investigated 288 municipalities in Sweden and analyzed the process and motives of LA 21.

Selman (2009) examined initiatives of local governments for LA 21 in Finland, The Netherlands, Sweden, Norway, UK, Germany, Poland and Southern Europe. Ellis et al. (2004) investigated the LA 21 for the Island of Ireland. They carried out a qualitative research and explained the general perception and situation of the LA 21 for the Island of Ireland. Kern et al. (2004) examined the process of LA 21 for Germany and they investigated four cities including Berlin, North RhineWestphalia, Bavaria, and Thuringia. Perkins and McDonagh (2012) investigated local governments' performance of promoting sustainable design of commercial buildings in New Zealand in the context of LA 21 program. They found that there were some gaps between sustainability policies and implementations. Zan and Ngah (2012) investigated the performance of implementing LA 21 program in Seberang Perai Municipal Council (in Malaysia) and they found that communities were favoured by the LA 21 program.

Municipalities and local governments have started to play a more effective role on environmental protection for the city depending on the process of Local Agenda 21. Most local governments have had their own Local Agenda 21 (LA 21) program which guides local governments about sustainability implementations and making lists and strategic planning for sustainable development in the world. These LA 21 process have been active since 1996 after Habitat II Conference in Istanbul. To reach sustainable development, local governments should take the responsibility and guide their citizens about environmental protection.

\section{MATERIALS AND METHODS}

This study employed qualitative research methods with case study. The necessary data were obtained from municipal staff through interview method in order to reveal the extent to which municipalities were successful in practicing sustainability implementations. The study municipalities are 5 district municipalities in Istanbul as seen in Figure 1. Each district municipality has approximately 500 regular officers so the target population is 2500 and the sample size is 50 . Interview method is a commonly used and preferred data acquisition method in qualitative researches which involves asking people some questions and obtaining their view about the related subject (Moriarty, 2011). The main goal is to conduct an in-depth interview with as few people as possible. In the interview, data were obtained from the sample group through semi-structured interview form since it had a certain control mechanism and was more reliable. The interview form, firstly, included some demographical information related to the people interviewed. Second, they were asked some questions related to the municipality. The last part of the form consisted of some questions about main perceptions related to essential sustainability implementations. The study adapted Bostanci's (2015) research which made grouping of sustainability implementation elements of local governments. Sustainability facilities of municipalities are divided in two: strategy/policy-based and project-based. These two groups are subcategorized later. Table 1 shows sustainability elements of the observed findings from Turkish Municipalities.

Turkey is a member of the International Council for Local Environmental Initiatives (ICLEI) and as such it is thought that Turkish municipalities can be a good case to investigate the sustainability perception of staff. When district municipalities of Istanbul are broadly observed in terms of their contributions to environmental sustainability, it is seen that municipalities usually conduct activities such as organizing and extending parks and green areas, raising environmental awareness, waste management and recycling services. Activities for the environment and public health, vaccinating and protecting street animals are also carried out by municipalities. Some distinctive implementations in the Environmental Offices such as fighting against global climate change, usage of renewable energy sources, organizing cycle lane and walk ways are conducted by some municipalities. "As a problem of a city and a citizen, environmental problems are of particular concern to municipalities. Main duties and authorities of municipalities on protection of the environment have characteristics of administrative services.

The environmental law, enacted for the first time in Turkey in 1983, was legislated in order to protect the environment, a common wealth of every living being, in accordance with the sustainable development principles. Concepts of environmental impact assessment and strategic environmental assessment were added to the Environmental law in 2006 with the law no.5497" (Keleş et al., 2012). When the explanations about the environment on the Metropolitan and Municipal laws are analyzed, according to the Metropolitan Municipal law numbered 5216 and dated $2004^{1}$, municipalities are in charge of "ensuring the protection of the environment, cultivated areas and water basins; afforesting; gathering non-sanitary enterprises, entertainment venues and other enterprises which have impacts on the environment and public health in certain areas of the city; adjusting building materials,

\footnotetext{
${ }^{1}$ Since articles on the environment of the Metropolitan Municipal Law have been discussed, the Metropolitan Municipal Law is used as reference instead of the Municipal law numbered 6360 on The Establishment of Fourteen Metropolitan Municipalities and Twenty-Seven Districts and Amendments at Certain Law and Decree Laws. The law numbered 6360 is related to the establishment of fourteen metropolitan municipalities, the law numbered 5216 keeps it validity for several subjects about metropolitan municipalities.
} 


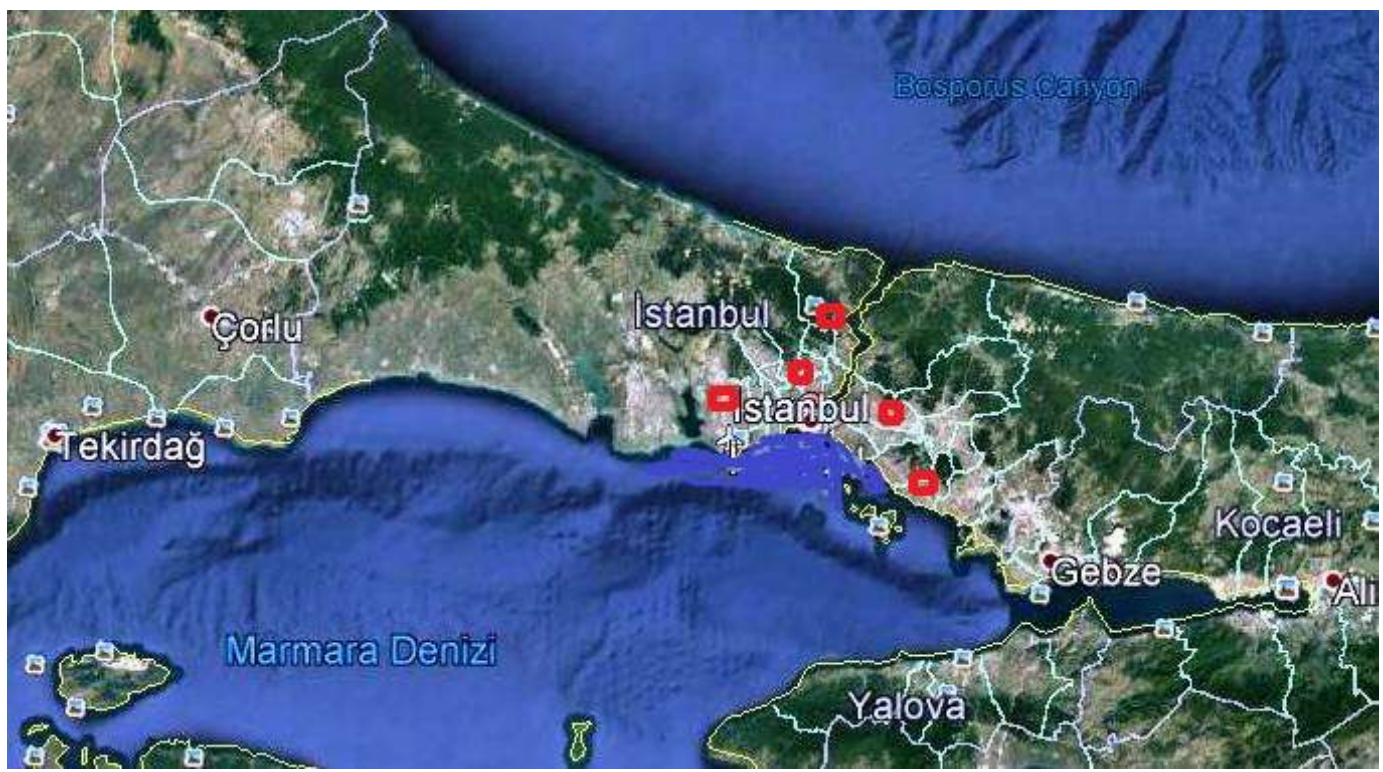

Figure 1. Map of the Study area, the district municipalities of Istanbul chosen for the research. Source: https://www.google.com.tr/int//tr/earth/

Table 1. Sustainability elements of the Turkish municipalities.

\begin{tabular}{ll}
\hline Strategy and policy-based implementations & Project-based implementations \\
\hline The Local Agenda 21 and City Councils & Sustainable Urban Planning \\
Strategies of environmental offices & Green Transportation Plans \\
Sister Municipalities & Waste Management and Recycling Projects \\
The European Union Funds for Sustainability & Precision of Environmental Sustainability on Urban Transformation Projects \\
International Municipality Organizations on Sustainability & Renewable Energy Projects for Sustainability \\
Social Activities to Promote Environmental Sustainability & Projects of Public Buildings with Green Certificate \\
Strategies to Decrease Emission & Projects of Energy Productivity for Buildings \\
- & Water Productivity Projects \\
\hline
\end{tabular}

Source. Adapted from Bostancı (2015).

junkyards and their selling areas, soil excavation, debris, sand and gravel yards, selling and storage areas of wood and coal; making solid waste management plans and implementing them; providing services related to reutilization, storage and disposing of solid waste and excavation except for collecting solid waste at the source and carrying them to the transfer station, providing services related to medical wastes, building necessary facilities, having them built, running them or having them run; collecting wastes of marine vessels, having them collected, refining them and making regulations about it." According to the Municipal Law numbered 5393 dated 2005, municipalities are in charge of "... the environment and environmental health, cleaning and solid waste; afforesting, parks and green areas;... gathering non-sanitary enterprises, entertainment venues and other enterprises which have impacts on the environment and public health in certain areas of city; adjusting storage areas of liquefied petroleum gas (LPG); solid excavation and debris discharge sites; adjusting building materials, junkyards and their selling areas; taking required precautions against environmental pollution."

The Municipal Law numbered 5393 defines City Councils as an agent of LA 21 and states that "City Council tries to improve the city vision and the awareness of citizenship, to protect the city's rights, to accomplish the principles of environmental awareness, sustainable development, social cooperation and solidarity, transparency, bringing to book and being brought to book, participation and decentralization." The law emphasized the importance of participation related to environmental problems with the following statement: "Municipalities carry out programs aimed for voluntary participation in order to create solidarity and participation in the city and to increase effectiveness in services, savings and productivity while organizing services for the environment." In the light of this information, it is seen that municipalities have significant responsibilities and obligations indicated by law. As practicing examples of green certification 
Table 2. Demographics of Participants

\begin{tabular}{llcc}
\hline Parameter & & $\mathbf{N}$ & $\%$ \\
\hline \multirow{2}{*}{ Gender } & Male & 23 & 36.0 \\
& Female & 27 & 54.0 \\
& $18-25$ & 1 & 2.00 \\
Age & $26-35$ & 24 & 48.0 \\
& $36-45$ & 13 & 26.5 \\
& $46-55$ & 9 & 18.0 \\
& 55 and upper & 1 & 2.00 \\
Education & College & 11 & 21.0 \\
& Bachelor degree & 30 & 60.0 \\
& Master degree & 9 & 18.0 \\
Experience of work & 5-10 years & 35 & 70.0 \\
& 10 years and upper & 13 & 26.0 \\
Total & & 2 & 4.00 \\
\hline
\end{tabular}

systems are increasing on the basis of buildings in Turkey, if this system is discussed in the agenda, it may provide important gains. After all, education and renewal activities and isolation of buildings for raising awareness of the public via cost and advertisement aspects may produce more effective results. The municipal services building of Küçükçekmece is among the first green-certified (BREEAM certified) buildings in Turkey. In a research carried out and applied to local participatory for sustainable development strategies in Turkey; features of social, environmental and economic sustainability in cities such as Istanbul, Antalya, Bursa, Yalova, Kars and Kastamonu were examined following the process of LA 21 with in-depth interview techniques (Varol et al., 2011). The findings of this study show that processes of LA 21 are among the main agents for sustainable development. When reports of the Union of Turkey City Council are examined, it is seen that city councils are founded in metropolitans, many cities and districts of many metropolitans. LA 21 organizations have been completed in more than 70 municipalities. Municipalities are now bound to finding city councils due to legislative regulations. City councils are defined in the article 76 of the Municipal law numbered 5393 and dated 2005. Practices of National and LA 21 has been developed in Turkey since 1996. Habitat II held in İstanbul became effective within this period (Arar, 2002).

The population included the staff of municipalities in Istanbul, Turkey. The sample group was determined considering purposive sampling method in order to gather the necessary information. The sample consisted of the staff from Istanbul. Municipalities were chosen based on criteria of being easily accessible and municipal staffs that were easy to access were included in the sample. Interviews were conducted on 50 participants from 5 municipalities randomly chosen. With regard to this study, it was thought that 50 persons to be interviewed would be efficient in order to have a better understanding about the subject as it was aimed to determine the extent to which municipalities had an active role in terms of sustainability implementations and accordingly to benefit from perceptions of municipal staff.

\section{RESULTS AND DISCUSSION}

In the sample group, all the district municipalities have their own Directory of Environmental Protection and Control. In this regard, municipalities conduct and control their environmental protection activities through these directories. In Table 2, some demographics of 50 participants (municipal staff) are presented. $36.0 \%$ of the participants $(n=23)$ were male and $54.0 \%(n=27)$ were female. Most of the participants $(n=24,48.0 \%)$ were in the age range of 26 to 35 years old and $26.5 \%$ of the participants were $(n=13)$ aged between 36 to 45 years old. The participants had jobs as supervisors at the municipality. So, as expected, most of them $(n=30$, $60.0 \%$ ) had a bachelor degree. For experience of work, most of the participants $(n=35,70.0 \%)$ had work experience of between 1 and 5 years.

Participants were required to evaluate basic issues about sustainability elements in the interview form and also to answer every issue in details. Table 3 presents the scores for sustainability implementations of municipalities. These scores examined how municipality staff evaluated the condition of sustainability implementation in the related local government. In this point, participants evaluated each category of sustainability implementations via options such as "sufficient or insufficient". Participants mostly said that 
Table 3. Sustainability elements in municipalities

\begin{tabular}{|c|c|c|c|}
\hline Strategy and policy-based implementations & & $\mathbf{N}$ & $\%$ \\
\hline \multirow{2}{*}{ The Local Agenda 21 and City Councils } & Sufficient & 39 & 78.0 \\
\hline & Insufficient & 11 & 22.0 \\
\hline \multirow{2}{*}{ Strategies of environmental offices } & Sufficient & 33 & 66.0 \\
\hline & Insufficient & 17 & 34.0 \\
\hline \multirow{2}{*}{ Sister municipalities } & Sufficient & 35 & 70.0 \\
\hline & Insufficient & 15 & 30.0 \\
\hline \multirow{2}{*}{ The European Union Funds for Sustainability } & Sufficient & 20 & 40.0 \\
\hline & Insufficient & 30 & 60.0 \\
\hline \multirow{2}{*}{$\begin{array}{l}\text { International Municipality Organizations on } \\
\text { Sustainability }\end{array}$} & Sufficient & 30 & 60.0 \\
\hline & Insufficient & 20 & 40.0 \\
\hline \multirow{2}{*}{$\begin{array}{l}\text { Social Activities to Promote Environmental } \\
\text { Sustainability }\end{array}$} & Sufficient & 37 & 74.0 \\
\hline & Insufficient & 13 & 26.0 \\
\hline \multirow{2}{*}{ Strategies to Decrease Emission } & Sufficient & 35 & 70.0 \\
\hline & Insufficient & 15 & 30.0 \\
\hline \multicolumn{2}{|l|}{ Project-based implementations } & $\mathbf{N}$ & $\%$ \\
\hline \multirow{2}{*}{ Sustainable Urban Planning } & Sufficient & 35 & 70.0 \\
\hline & Insufficient & 15 & 30.0 \\
\hline \multirow{2}{*}{ Green Transportation Plans } & Sufficient & 37 & 74.0 \\
\hline & Insufficient & 13 & 26.0 \\
\hline \multirow{2}{*}{ Waste Management and Recycling Projects } & Sufficient & 41 & 82.0 \\
\hline & Insufficient & 9 & 18.0 \\
\hline \multirow{2}{*}{$\begin{array}{l}\text { Precision of Environmental Sustainability on } \\
\text { Urban Transformation Projects }\end{array}$} & Sufficient & 20 & 40.0 \\
\hline & Insufficient & 30 & 60.0 \\
\hline \multirow{2}{*}{ Renewable Energy Projects for Sustainability } & Sufficient & 20 & 40.0 \\
\hline & Insufficient & 30 & 60.0 \\
\hline \multirow{2}{*}{$\begin{array}{l}\text { Projects of Public Buildings with Green } \\
\text { Certificate }\end{array}$} & Sufficient & 35 & 70.0 \\
\hline & Insufficient & 15 & 30.0 \\
\hline \multirow{2}{*}{ Projects of Energy Productivity for Buildings } & Sufficient & 15 & 30.0 \\
\hline & Insufficient & 35 & 70.0 \\
\hline \multirow{2}{*}{ Water Productivity Projects } & Sufficient & 36 & 72.0 \\
\hline & Insufficient & 14 & 28.0 \\
\hline \multicolumn{2}{|l|}{ Total } & 50 & 100.0 \\
\hline
\end{tabular}


strategy and policy-based implementations were more sufficient than project-based implementations. Although waste management was in the group of project base implementations, it gained the most positive score. As expected, practical implementations such as project, buildings etc. had lack of information and operation. Although local governments join LA21 program and make new plans for sustainable development, some areas such as engaging in projects or using alternative and sustainable energy resources are still in progress.

According to the aim of the study, each category was conducted for environmental sustainability elements of municipalities as follows:

Issue 1, Studies related to the Local Agenda 21 and city councils: Turkey is a member of ICLEI and also UCLG - MEWA (United Cities and Local Governments Middle East and West Asia Section) such that the Turkish local government has conducted many studies about The LA 21 since 1990s (OECD, 2008). Accordingly, the staffs of municipalities are aware of environmental sustainability and the LA 21 program. Most of the participants $(n=39$, $78.0 \%$ ) said that the related municipality implemented the LA21 program and they understood the need for LA21. In addition, they thought that city councils were informed about sustainability tools and there was a partnership between municipalities and city councils with regard to LA21 program.

Issue 2, Strategic plans are made in directories of environmental protection considering legislations of municipality on sustainability: With the help of LA21 program, Turkish municipalities have begun to make sustainable strategies and planning. $66.0 \%$ of the participants $(n=33)$ said that there were strategic planning and implementation plans in environmental offices of the related municipality. The staff of municipality knew sustainable management system and organizational structure. The law also helps staff to make new sustainable planning and implementation. Accordingly, it can be said that Turkish municipalities has made environmental management system for the long-term through its law and tasks.

Issue 3, Environmental protection projects are planned in the relationship of sister municipalities: $70.0 \%$ of participants $(n=35)$ determined that their municipalities had a collaboration with sister municipalities to study environmental protection projects. So this result is coherent with the present study. Not only in the country but also outside the country is there so many partnerships between Turkish municipalities and others. For example, Municipality of Emirdağ (in Turkey) had a project of "Integrated Solid Waste Management" with Municipality of Haarlem (in Holland). Municipality of
Antalya (in Turkey) had collaboration with Municipality of Malmö (in Sweden) for the projects such as "sustainable social, economic and environmental development" (TBB, 2012).

Issue 4, Sustainability implementations are carried out benefiting from the European Union Funds: $60.0 \%$ of participants $(n=30)$ said that implementations of the European Union Funds were insufficient. Municipal staff ascertained that they knew about the European Union Funds but there were some lack of carrying out project development or implementation.

Issue 5, Municipalities joined to international municipality units for sustainability implementations: $60.0 \%$ of participants $(n=30)$ determined that the related municipalities joined international organizations for sustainability implementations. In other words, participants were aware of international organizations that lead sustainable implementations. Being a member of ICLEI and UCLG - MEWA, Turkish municipalities often involve in international conferences or meetings to obtain recent sustainable implementations or new sustainable projects for local governments.

Issue 6, Social activities for environmental protection and sustainability are organized: Most participants $(n=37,74.0 \%)$ agreed that the related municipalities organized social activities for environmental protection and sustainability. So, it can be said that municipal staff thought that municipalities took the responsibility for sustainable development and they guided citizens for environmental sustainability.

Issue 7, Strategies of decreasing emission are included in municipality's legislations: $70.0 \%$ of them $(n=35)$ determined that municipalities regulated local laws for decreasing emission in the city. For example, Istanbul Metropolitan Municipality has some implementations to decrease Istanbul's carbon footprint. Istanbul Metropolitan Municipality joined the UNFCCC-COP 15. Istanbul's emission inventory was shared to the public and the feasibility of Istanbul's Climate Change Action Plan was completed (Istanbul Metropolitan Municipality, 2017).

Issue 8, Urban plans are made in accordance with sustainable environmental projects: $70.0 \%$ of participants $(n=35)$ agreed that municipalities were successful at sustainable urban planning. Urban plans are important elements for sustainable environment because urban areas can save the environment when there is a great urban planning and habitat.

Issue 9, Green transportation planning are conducted: $74.0 \%$ of participants $(n=37)$ agreed that 
they did not find green transportation plans sufficient. In other words, there were troubles in green transportation. This issue is related with practical implementations, and a municipal staff said that municipalities can develop many projects but some limits such as budget, time etc. hinder the operations in practice.

Issue 10, Municipalities have waste management and recycling projects for the city: Most participants $(n=41$, $82.0 \%$ ) agreed that municipalities had sufficient projects for waste management and recycling in the city. Accordingly, it can be said that local governments have begun waste management and recycling since LA 21 program and they have kept alternative projects for recycling in the long-term.

Issue 11, Policies of environmental protection are regarded within the period of urban transformation: $60.0 \%$ of participants $(n=30)$ agreed that precision of environmental sustainability on urban transformation projects were insufficient for the city. Municipalities still have some troubles in urban transformation projects without environmental protection in the long-term.

Issue 12, Renewable energy projects for buildings are conducted collaboratively by municipalities and their partners (such as solar and wind energy): Most participants $(n=30,60.0 \%)$ agreed that renewable energy projects for buildings were insufficient in the city. Municipalities should improve their renewable energy projects both for the buildings and city.

Issue 13, Municipalities have incentive approaches on being green-certified for public buildings: $70 \%$ of participants $(n=35)$ agreed that projects of public buildings with green certificate were sufficient. So it is clear that local governments are more successful in sustainable development. Because local governments such as municipalities engage in sustainability program, they can adapt sustainability implementations more quickly.

Issue 14, Municipalities carry out inspections in order to provide energy productivity of buildings: There is a problem in providing energy productivity for the entire city. $70.0 \%$ of participants $(n=35)$ agreed that projects of energy productivity for buildings were insufficient. This result has also proved that municipalities cannot provide environmental sustainability for private buildings.

Issue 15, Municipalities have water productivity projects and control implementations of water productivity: Most participants $(n=36,72.0 \%)$ agreed that water productivity projects were sufficient. Municipalities have well developed water productivity projects in the city for a long time and they provide clean water for the entire city on demand.

\section{Conclusion}

Environmental sustainability has a key role in sustainable development and the first responsibility belongs to regional and local governments. Local governments which are closer to the public should be more careful about environmental protection. As explained in the LA 21 program, local governments should engage in sustainable implementations for city management in the long-term if they want to keep sustain it for next generation. The literature has shown that investigating environmental sustainability performance of local governments is also extremely important. Determining performance of local governments in environmental sustainability will help them to support sustainable development.

This paper also investigated perceptions and views of municipal staff for environmental sustainability implementations of the municipalities in Istanbul, Turkey. Accordingly, we determined how municipal staff perceives environmental sustainability performance of the local governments. This study employed qualitative research and collected data via interviews. The findings indicated that local governments were more successful in planning and management level of environmental sustainability implementations. This finding is coherent with the theory because as being a member of ICLEI and UCLG-MEWA, 2016). Turkish municipalities have joined the LA 21 program and they have adapted new environmental sustainable management approach since 1990s. On the other side, local governments were insufficient in practical implementations of environmental sustainability projects such as green buildings, renewable energy, and sustainable buildings in the city.

Although local governments can adopt environmental implementations for their buildings, personnel etc. easily, they have some troubles to adapt these environmental implementations for all the citizens in the city. This can be a big problem for the future because local governments should adapt the citizens to sustainable development similar to the municipalities. With the thought that implementation of LA 21 program is not so easy (Mehta, 1996), over time, local governments will be guided to find the best way to greatly adopt sustainability implementation. In addition, ICLEI can be a good guide for local governments to learn how LA 21 program can be adopted (Mehta, 1996). Turkey still keeps ICLEl's guidance for sustainable development and its local government has advanced in living standards with sustainability.

Prior literature has found that LA 21 program changed 
based on the local government and the city because there is not only one type of LA 21 program in the world. Each local governments of the world adopt different programs. Accordingly, it is suggested that local governments should find the most proper program to support sustainable development goals in the city.

NOTE: Parts of the study was presented in ICOMEP (International Congress of Management Economy and Policy), 2016 October in Istanbul, Turkey.

\section{CONFLICT OF INTERESTS}

The authors have not declared any conflict of interests.

\section{REFERENCES}

Arar AA (2002). Yerel Gündem 21 (The Local Agenda 21). Dışişleri Bakanlığı Yayınları, Uluslararası Ekonomik Sorunlar Dergisi. VI Retrieved from http://www.mfa.gov.tr/yerel-gundem-21.tr.mfa (accessed 15 July 2017).

Atvur S (2009). Local Agenda 21 and Environment: The Case of Antalya City Council. CU J. Soc. Sci. 35(2):231-241.

Bostancı SH (2015). Sustainability Strategies and Projects of Turkish Municipalities. (Eds. Ken D. Thomas). Handbook of Research on Sustainable Development and Economics 4:56-71. IGI Global.

Connelly S (2002). Public Involvement in Local Agenda 21: The Impact Of Local Authority Policy Processes. Department of Town and Regional Planning, University of Sheffield, September Thesis submitted for the degree of $\mathrm{PhD}$.

Eckerberg K, Forsberg B (1998). Implementing Agenda 21 In Local Government: The Swedish Experience. Local Environment 3(3):333347.

Ellis G, Motherway B, Neill-William JV, Hand, U (2004). Towards A Green Isle? Local Sustainable Development on the Island of Ireland. A Report for the Centre for Cross Border Studies. January 2004.

Emas R (2015). Brief for GSDR 2015. The Concept of Sustainable Development: Definition and Defining Principles. Retrieved from https://sustainabledevelopment.un.org/content/documents/5839GSD R\%202015_SD_concept_definiton_rev.pdf (accessed 15 June 2017).

International Conference on Language, Education and Innovation (ICLEI) (2017). About ICLEI. Who we are, Retrieved from http://www.iclei.org/about/who-is-iclei.html (accessed 15 June 2017). Issues from The South. Environ. Impact. Assess. Rev. 1996(16):309320.

Istanbul Metropolitan Municipality (2017). Investments. Environment, Retrieved from https://www.ibb.istanbul/Investments/CatalogResult/3 (accessed 31 July 2017).

Kates RW, Parris, TM, Leiserowitz AA (2016). Editorial-What Is Sustainable Development? Goals. Indicators. Values and Practice. Environment Science and Policy for Sustainable Development. Retrieved from http://www.cepn-paris13.fr/epog/wpcontent/uploads/2016/01/CONSOLO_Kates-et-al.pdf (accessed 15 July 2017).

Keleş R, Hamamcı C, Çoban A (2012). Çevre Politikası. Ankara: İmge Kitabevi Yayınları.

Kern K, Koll C, Schophaus M (2004). Local Agenda 21 in Germany: An inter - and intranational comparison, WZB Discussion Paper, No. SP IV 2004-104.

KOMMUNESPEILET (2016). Role of Local Governments in the Implementation of the Sustainable Development Goals, Retrieved from http://www.ks.no/fagomrader/samfunn-og demokrati/internasjonalt-samarbeid/ks-i-verden/role-of-localgovernments-in-the-effective-implementation-of-the-sustainabledevelopment-goals/ (accessed 15 June 2017).

Lafferty WM, Eckerberg K (2009). From Earth Summit to Local Agenda 21-Working Towards Sustainable Development. Earthscan.

Mehta P (1996). Local Agenda 21: Practical Experiences and Emerging

Moriarty J (2011). Qualitative Methods Overview. NIHR. School for Social Care Research London School of Economics and Political Science Houghton Street London.

Organisation For Economic Co-Operation and Development (OECD) (2008). Environmental Performance Reviews Turkey 2008. (OECD Çevresel Performans Incelemeleri). Turkish edition. published by: Ministry of Environment and Foresty, Retrieved from http://www.oecd.org/environment/country-reviews/42198785.pdf (accessed 20 July 2017).

Partnership for Local Agenda 21 (1999). Local Agenda 21 - The South Australian Experience. (Guidelines and Ideas for Local Government to Develop a Local Agenda 21 Program). Department for Environment. Heritage and Aboriginal Affairs and the Local Government Association South Australia March 1999 Retrieved from https://www.lga.sa.gov.au/webdata/resources/project/LA21_text.pdf (accessed 15 July 2017). performance. Sustainability: Sci. Pract. Policy 6(1):18-27.

Perkins M, McDonagh J (2012). New Zealand Local Government Initiatives and Incentives for Sustainable Design in Commercial Buildings. European Real Estate Society (ERES) (No. eres2012_057), Retrieved from: https://eres.architexturez.net/system/files/pdf/eres2012_057.content. pdf (accessed 30 July 2017).

Roberts D, Diederichs N (2002). Durban's Local Agenda 21 Programme: Tackling Sustainable Development In a Post-Apartheid City. Environ. Urban. 14(1):189-201.

Scipioni A, Mazzi A, Mason M, Manzardo A (2009). The Dashboard of Sustainability to Measure the Local Urban Sustainable Development: The Case Study of Padua Municipality. Ecol. Indic. 9:364-380.

Selman P (2009). Local Authorities Initiatives in Support of Agenda 21 Europe, Area Studies - Europe (Regional Sustainable Development Review). (Eds. Mather, A. and Bryden,J.), Encyclopedia of Life Support Systems (EOLSS) Oxford, United Kingdom. pp.136-159.

Strong M, Dowdeswell E (1996). The Local Agenda Planning Guide: An Introduction to Sustainable Development Planning. The International Council for Local Environmental Initiatives (ICLEI) Local Agenda 21, The International Development Research Centre (IDRC) and The United Nations Environment Programme (UNEP).

Sustainable Environment (2017). Local Agenda 21. Retrieved from http://www.sustainableenvironment.org.uk/Action/Local_Agenda_21.php (accesed 15 Jul 2017).

Tanguay GA, Rajaonson J, Lefebvre JF, Lanoie P (2010). Measuring the Sustainability of Cities: An Analysis of the Use of Local Indicators. Ecol. Indic. 10:407-418.

The Environment of the Czech Republic (CENIA) (2008). The Local Agenda 21, Retrieved fromhttp://www.cenia.cz/web/www/webpub2.nsf/\$pid/CENMSFVZ8V R3/\$FILE/local_agenda21.pdf (accessed 15 July 2017).

The United Nations Conference on Environment and Development (UNCED) (1992). United Nations Conference on Environment \& Development Rio de Janerio. Brazil. 3 to 14 June 1992 Agenda 21, Retrieved from https://sustainabledevelopment.un.org/content/documents/Agenda21. pdf (accessed 15 July 2017).

UCLG-MEWA (United Cities and Local Governments Middle East and West Asia Section) (2016). Habitat III Conference 2016, Retrieved from http://uclg-mewa.org/hab\%C4\%B1tat\%C4\%B1\%C4\%B1\%C4\%B1-konferansi/ (accessed 30 July 2017).

Union of Municipalities of Turkey (TBB) (2012). Kardeş Şehirler: Uluslararası Belediye İşbirlikleri ve Birliğimizin Rolü. İller ve 
Belediyeler. 2012 December. 776: 6-15.

United Cities and Local Governments (UCLG) (2015). Sustainable Development Goals: What Local Governments Need to Know, Retrieved

https://www.uclg.org/sites/default/files/the_sdgs_what_localgov_need to know 0.pdf (accessed 15 June 2017).

United Nations Environment Programme (UNEP) (1972). Report of the United Nations Conference on the Human Environment. Stockholm 5-16 June 1972. United Nations, Retrieved from http://www.undocuments.net/aconf48-14r1.pdf (in Accessed 15 June 2017). Upadhyay N, Brinkmann R (2010) (Spring). Green Local Governments in Florida: Assessment of sustainability

Varol C, Ercoskun OY, Gurer N (2011). Local Participatory Mechanisms and Collective Actions for Sustainable Urban Development in Turkey. Habitat. Int. 35(1):9-16.
Yıldırım S, Yıldırım DÇ, Gedikli A (2016). Sustainable Consumption Trends in the World in the Context of Green Economy and Sustainability. (Eds. Erdoğdu. MM. Arun T, Ahmad IH). Handbook of Research on Green Economic Development Initiatives and Strategies IGI Global. 4:66-84.

Zan ZM, Ngah K (2012). Local Agenda 21 Program Effectiveness in Seberang Perai Municipal Council, Penang, Malaysia. OIDA Int. J. Sustain. Dev. 4(6):25-30. 